\title{
PROTECTIVE COMMITTEES AND DEPOSIT AGREEMENTS IN RAILROAD REORGANIZATIONS
}

\author{
BY WILLIAM G. FENNELL $\dagger$
}

ONE result of increased supervision of business management in the last few years has been to direct attention toward remodeling railroad reorganization procedure, ${ }^{1}$ and to control it at the outset. By the addition of subsection ( $p$ ), ${ }^{2}$ in 1935, to Section 77 of the Bankruptcy Act a system of control has, to a degree, been realized over one of the most vital factors in railroad reorganization, the protective committee. From the authority over protective committees in railroad reorganizations granted the Interstate Commerce Commission by this amendment, a comprehensive scheme of regulation of the personnel of committees, the terms and conditions of deposit agreements, authorizations and proxies, and solicitation of railroad securities has been developed, under rules and regulations promulgated by the Commission. ${ }^{3}$ The purpose of this Article is to describe the procedure which protective committees must follow under the present regulations, to examine the regulations under which such protective committees at present function, in the light of policy, and analogous regulation of protective committees in the reorganization of corporations other than railroad corporations, and to study the requirements developed by the Commission for deposit agreements, authorizations and proxies. ${ }^{4}$

\section{Background of Section 77( $p)$}

Section 77 was enacted early in March, 1933 "after hurried consideration, just before the Hoover administration went out of office." It contained no provisions for the regulation of protective committees or the regulation of the solicitation of proxies to represent railroad securitics in reorganization. Consequently, until 1935 when subsection ( $p$ ) was added to Section 77 by amendment, the only regulation of such committees was under the Securities Act of 1933, whereby, pursuant to regulations adopted by the Securities and Exchange Commission, ${ }^{\circ}$ a

$\dagger$ Member of New York Bar.

1. Douglas, Protective Committees in Railroad Reorganizations (1934) 47 Hanv. L. Rev. 565; Lowenteal, The Investor Pays (1933); Lowenthal, The Railroad Reorganization Act (1933) 47 HARv. L. REv. 18.

2. 49 Stat. $923-925$ (1935); 11 U. S. C. $\$ 205$ (p) (Supp. 1938).

3. Regulations governing applications under Section $77(\mathrm{p})$, etc., established by an order issued at a General Session of the Interstate Commerce Commission on October 23, 1935 ; C. C. H. Bankr. Serv. $\llbracket 7101$ (1935).

4. Neither the Wheeler Bill, SEN. R. 1869, 76th Cong., 1st Sess. (1939), nor the Lea Bill, H. R. 4862, 76th Cong., 1st Sess. (1939), which make extensive amendments to Section 77 contemplate any except minor changes in subsection (p).

5. Senator Wheeler in 79 Covg. Rec. 14231 (1935).

6. Until 1934 regulation was by the Federal Trade Commission. 
registration statement for certificates of deposit of such committees was required to be filed. ${ }^{7}$ With the enactment of the Securities Exchange Act of 1934, protective committees for railroad securities having their certificates of deposit listed on a national securities exchange were required to file a listing application under the applicable provisions of that Act. $^{8}$

Such regulation, however, in respect to certificates of deposit of protective committees was designed (as in the case of other securities subject to these Acts) to insure the publication of essential and truthful information about securities offered for sale. They were not designed to, and did not attempt to regulate the provisions of deposit agreements (except indirectly), or to pass upon the personnel of committees. ${ }^{9}$

But the extensive amendments to Section 77 adopted in 1935 broadened the authority of the Interstate Commerce Commission to include public supervision of the activities of protective committees, particularly of the issuance of certificates of deposit. As described by Chairman Wheeler of the Senate Interstate Commerce Committee, the amendments carried "provisions enabling comprehensive regulation of such committees, the purpose being to protect the public and the companies against exploitation, such protection being impossible under the present law." 10

So earnest were the legislators to carry out their avowed purpose that the original bill ${ }^{11}$ as reported ${ }^{12}$ from the Committee entirely eliminated compensation and permitted reimbursement to protective committee members only for actual and reasonable expenses. Representative Celler, however, took the position that this change was too drastic. ${ }^{13}$ As a result a compromise was struck, ${ }^{14}$ providing that under the section actual and reasonable expenses (including reasonable attorneys' fees within maximum limits fixed by the Interstate Commerce Commission) may be reimbursed to committees from the debtor's estate, but no compensation may be allowed to committees from the debtor's estate. ${ }^{15}$

7. The prescribed form is $\mathrm{D}-1$.

8. 48 Stat. 881 (1934), 15 U. S. C. $\$ \$ 7 \& a-7 \$ j j$ (1934). The preserited form for certificates of deposit is Form 14.

9. This is not to imply that the Securities and Exchange Commission may not compel changes in personnel by use of its powers to stop a registration statement from treoming effective. Matter of Bondholders' Committee for Republic of Colombia Dollar Bonis, S. E. C. Release No. 1631 (1937).

10. See note 5 supra; SEN. ReP. No. 1336, 74th Cong., 1st Sess. (1935).

11. H. R. S587, 74th Cong., 1st Sess. (1935).

12. H. R. REP. No. 1283, 74th Cong., 1st Sess. (1935).

13. Id. at 6 .

14. See note 5 supra at 13777.

15. See note 2 sipra; 49 STAT. $916-917$ (1935), 11 U. S. C. $\$ 205$ (c) (12) (Surp. 1939). Senator Wheeler's pending bill would permit a committee to obtain reasonable compensation from the estate if its services were of henefit to the estate. It also gives a committee a lien on securities distributed to a class of creditors or stocliholders for whese 


\section{Scope and summary of subsection ( $p)$}

Subsection ( $p$ ) makes it unlawful, until authorization has been obtained from the Interstate Commerce Commission, for any person "during the pendency of proceedings" under Section 77, "or of receivership proceedings against a railroad corporation in a State or Federal Court" to solicit proxies or deposits without first obtaining the approval of the Commission. ${ }^{16}$

There are, however, two exceptions to the general requirement. First, an individual security holder, if he is not part of an organized effort, and is acting in his own interest and not for anyone else, may act through a representative, or may authorize a representative to act for him. This exception obviously is to protect the right of a single security holder to appear in the proceeding by counsel if he so elects. The second exception is more important and exempts from the necessity of obtaining authority "groups of not more than twenty-five bona fide holders of securities or claims," or "groups of mutual institutions from acting together for their own interest and not for others." Such "groups" may also authorize representatives to act for them in the proceedings. The obvious advantages of this latter. form of representation is likely to result in its increased use by life insurance company groups and other institutional holders. ${ }^{17}$ Also exempted from the provisions of the stibsection are persons or committees who have commenced solicitation prior to the effective date of the amendatory section, that is, August 22, 1935. This exception is significant since a great many railroad reorganizations did commence before that time. However, such committees must bear in mind the coercive features of the proviso clause pertinent to such exempted committees.

An interesting problem is raised where the deposit agreement of a protective committee, which was originally entitled to exemption because solicitation commenced prior to August 22, 1935, expires by its terms after that date. In several cases, ${ }^{18}$ committees have deemed it advisable to apply to the Commission under the subsection for authority to continue to act, and have thus become subject to the Commission's jurisdiction. In such a situation the subsection provides, however, that the

benefit a committee is found by the court, after notice and hearing, to have rendered services. See note 4 supra.

16. See note 2 supra.

17. Chicago, I. \& L. Ry. Reorg., 221 I. C. C. 549,550 (1937) indicates that the experience of many insurance companies shows that when they participate in the ustal protective committee with "little holders" the insurance companies bear the brunt of the expenses.

18. Chicago, R. I. \& P. Ry. Reorg., 221 I. C. C. 435 (1937) ; Missouri Pacific R. R. Reorg., 230 I. C. C. 5 and 377 (1938); Minneapolis \& St. L. R. R. Receivership, 233 I. C. C. 93 and 350 and 605 (1939). 
"authorization shall not be upon terms which shall invalidate any action theretofore taken, or any rights or obligations which have theretofore arisen." A committee whose deposit agreement terminates without an explicit power to extend it, or a committee with a deposit agreement which permits depositors to withdraw upon the lapse of a certain period of time, or the happening of a certain event, may be faced with the choice of either registering its extended certificates of deposit under the Securities Act of 1933, or of applying to the Interstate Commerce Commission under Section $77(\mathrm{p})$. A committee subject to Section $77(\mathrm{p})$, however, is automatically exempted from the registration requirements of the Securities Act of 1933 by Section 77, subsection (f) (4). ${ }^{10}$ Committees subject to subsection $(p)$ are also exempt from the proxy provisions of the Securities Exchange Act of $1934 .^{20}$ If, however, certificates of deposit of a committee subject to subsection ( $p$ ) are registered on a national securities exchange, such certificates must be registered under the Securities Exchange Act of 1934 with the Securities and Exchange Commission. Furthermore, if a committee, previously exempt because it commenced to solicit prior to August 22, 1935, elects to apply for and obtains authority under Section $77(\mathrm{p})$, because of the subsequent expiration of its deposit agreement or doubt of the committee's power to extend it, a new listing application may have to be filed with the Securities and Exchange Commission. ${ }^{21}$ This is based upon the theory that the extension of the agreement constitutes the committee a "new issuer" and makes of the extended certificates of deposit a "new security."

Thus a committee for railroad securities must (under normal circumstances) secure the approval of the Interstate Commerce Commission before commencing solicitation and must file monthly reports with that body. In addition, if its certificates are registered on a stock exchange, it must file a listing application with the Securities and Exchange Commission and file the required annual and periodic reports with that body."

19. Section 77 (f) reads: "The provisions of title I and of Sec 5 of the Securities Act of 1933, as amended, shall not apply to the issuance, sale or exchange of any of the following securities and transactions therein shall, for the purposes of said Securities Act, be treated as if they were specifically mentioned in sections 3 and 4 of the said Securities Act, respectively : . . (4) all certificates of deposit representing securities of, or claims against, the debtor, with the exception of such certificates of deposit as are issued by committees not subject to subsection (p) hereof."

20. 49 Stat. 920 (1935), 11 U. S. C. $\$ 205$ (f) (Supp. 1938), last sentence.

21. The form prescribed is Form 8B, "For Securities Issued in Certain Cases upon the Registrant's Succession to an Issuer or Issuers of Previously Registered Sceurities." Where there is no doubt of the committee's power to extend an agreement, only an 8-K current report need be filed.

22. 4S Stat. 888 (1934), 15 U. S. C. \&78h (1934). Rules and Regulations under the Securities Exchange Act, Rules X-13A-1 ff. 


\section{Procedure to obtain anthority}

The entire procedure for obtaining the authority required by subsection (p) is set forth in Rules and Regulations adopted by the Commission. The Rules require the filing of an application containing detailed information about the committee members, their relations to underwriters, the trustee and the debtor, their proposed financial arrangements and the proxy, authorization or deposit agreement under which they propose to take action. ${ }^{23}$ After the application has been duly filed, a hearing is held before an examiner. These hearings, unless there is opposition, are not extended, and afterwards a director of the Commission will often correspond with counsel as to amendments to the deposit agreement proposed by the Commission. If agreeable to the committee and counsel, these may be accepted forthwith and deemed amendments to the application and the exhibit attached. If not acceptable, negotiation may continue until the director and the committee are in agreement.

The Commission will grant the application "only if it finds that the terms and conditions upon which such solicitation, use, employment or action is proposed are reasonable, fair, and in the public interest, and conform to such rules and regulations as the Commission may provide." 24 The Commission is empowered to modify any order by a stupplemental order, and may not invalidate action previously taken, or rights or obligations which have previously arisen in conformity with the Commission's prior order. ${ }^{25}$

It is apparent that the regulation of protective committees for railroad securities by the Interstate Commerce Commission is extensive and strict. But before considering in more detail the reported decisions of the Commission upon applications under Section $77(\mathrm{p})$ in the light of these rules, it may be enlightening to compare the present regulation of protective committees for railroad securities to the regulation of protective committees in other types of reorganization. For example, former Section

23. See note 3 supra. In the case of a committee which has been active before August 1935, and which is seeking "authority to continue to act," it is advisable to submit the deposit agreement with such changes as the committee is willing to make in line with the Commission's decisions. This avoids a denial of the application in most cases and permits the Commission to grant authority on condition that such further changes be made as it deems necessary.

24. See note 2 supra.

25. Id. at $\llbracket 2$. The Commission is given broad investigatory powers in $\llbracket 3$. Penalties for violation of the section or the rules and regulations pursuant to it are prescribed by $\pi 4$. These apply also to anyone who wilfully and knowingly makes a false and misleading statement with respect to a material fact in the application. Violations are punishable by a fine of not less than $\$ 1,000$ or more than $\$ 10,000$ and/or imprisonment for not less than one or more than ten years. "But no person shall be subject to imprisonment under this section for the violation of any rule or regulation if he proves that he had no knowledge of such rule or regulation." 
77B of the Bankruptcy Act contained no analogous regulatory provisions. ${ }^{26}$ Chapter $\mathrm{X}^{27}$ contains provisions requiring every person or committee representing more than twelve creditors or stockholders who appear in the proceeding to file with the court a statement under oath which shall include a copy of the instrument under which the committee proposes to act, the amounts of stock of the debtor owned by members of the committee and when such stock was acquired..$^{23}$

In such a proceeding, the judge may examine and disregard any provision of a deposit agreement, proxy or power of attorney; may enforce an accounting thereunder; may restrain the exercise of any power which he finds to be unfair or not consistent with public policy; and finally may limit any claim on stock acquired by a committee in contemplation or in the course of the proceeding to the actual consideration paid therefor. ${ }^{29}$ Committees may not be allowed to intervene until they have satisfied the court that they have complied with the applicable laws regulating the activities and personnel of committees. ${ }^{30}$ This, apparently, refers to the applicable provisions of the Securities Act, and if certificates of deposit are registered on a national securities exchange, also to the Securities Exchange Act. ${ }^{31}$

A bill was introduced in the House in 1937 by Representative Lea which provided even more stringent regulation of protective committees in ordinary corporate reorganizations than the regulation of committees pursuant to Section $77(\mathrm{p})$ in railroad reorganizations. ${ }^{32}$ Purportedly, ${ }^{33}$ it was based upon the Securities and Exchange Commission's Protective Committee study ${ }^{34}$ and was understood to have the backing of the Commission. Briefly, it provided that no solicitation of securities could be made in interstate commerce unless a "declaration" had become effective as to the solicitation, and a prospectus meeting the requirements of the Act accompanied the solicitation. ${ }^{35}$ Various grounds were afforded the Commission upon which to refuse to permit the solicitation. ${ }^{30}$ but it is unnecessary to summarize the bill here. Suffice it to say, its passage would have resulted in a most stringent regulation of protective committees in reorganizations other than in the railroad field. At the same time, it

26. 48 Stat. 912 (1934), 11 U. S. C. \$207 (1934).

27. 52 Stat. $\$ 83$ (1938), 11 U. S. C. $\$ 501$ et seq. (Supp. 1938).

28. 52 Stat. 895 (1938), 11 U. S. C. $\$ \$ 611-613$ (Supp. 1938).

29. Id., at Section 612.

30. Id., at Section 613.

31. 48 STAT. 74-95, 881 et seq., 15 U. S. C. $\$ \$ 77 \mathrm{a}-78 \mathrm{jj}$ (1934).

32. H. R. 6968, 75th Cong., 1st Sess. (Comm. Print No. 2, 1937).

33. Id. at $302(\mathrm{a})$.

34. 48 STAT. 909 (1934), 15 U. S. C. \$77jj (1934).

35. H. R. 6968, 75th Cong., 1st Sess. (Comm. Print No. 2, 1937, $\$ 305(a)$ )).

36. Id. at $\$ \S 307(\mathrm{a}), 308$. 
would have "equalized" the regulatory provisions applicable to the two types of reorganizations. ${ }^{37}$

As the matter now stands, railroad reorganization committees are subject to the strict regulations imposed by Section $77(\mathrm{p})$. Other reorganization committees need only comply with the regulations of the Bankruptcy Act, which seem by comparison much less stringent. ${ }^{38}$ Nevertheless, Section 212 of that Act will remain a potential source of regulation until its limits have been more precisely settled by judicial definition. While a suggested ${ }^{39}$ system of regulation which would supply control of protective committees "at the time of their constitution" has been realized in railroad reorganizations, it has not yet been realized under present legislation as to other committees.

\section{Regulation of personnel under Section $77(p)$}

Although subsection (p) of Section 77 has no prohibitory provisions such as were contained in the Lea bill, ${ }^{40}$ which forbade underwriters and beneficial owners of securities to be members of committees, the regulations of the Interstate Commerce Commission require much information about the personnel of the committee in the application. ${ }^{41}$ Under its authority to deny an application if terms and conditions are not "in the public interest," the Commission has on occasion made it a condition of granting authority requested that a particular person be taken off the committee because of his affiliations or his ownership of securities. In the Chicago, Indianapolis \& Louisville Railway Company Reorganization, $^{42}$ the Commission conditioned a grant of authority to a committec for first and general mortgage bonds on the withdrawal of a member of a firm, the predecessor of which had underwritten securities which the committee sought to represent. It is mentioned in the opinion that he owned shares of stock of the road. On the other hand, in the Missouri Pacific Railroad Reorganization ${ }^{43}$ it appeared that an applicant was a member of the firm of underwriters who underwrote the security, but the application was granted without comment on this point. Another striking example where the Commission authorized a committee organized by the underwriter is that of Plaza-Olive Building Committee in the Missouri

37. See note 32 supra. The bill was never enacted. Information from Hon. Clarence F. Lea, Chairman, Committee on Interstate and Foreign Commerce. See Rostow and Cutler, Competing Systems of Corporate Reorganization: Chapters $X$ and $X I$ of the Bankruptcy Act (1939) 48 YALE L. J. 1334.

38. See note 28 supra.

39. See Douglas, sutpra note 1 , at 566-567.

40. See note 32 silpra.

41. See note 3 supra at $5,9(\mathrm{c}),(\mathrm{n}),(0)$ and (r).

42. 221 I. C. C. 549 (1937).

43. 230 I. C. C. 377 (1938). 
Pacific Railroad Company Reorganization." Consequently, it is impossible to say that in every case an underwriting affiliation will disqualify an applicant. Just where the Commission will draw the line is difficult to determine. In exercising its administrative function, the Commission may decide that in a specific case such an affiliation is not a disqualification as in the Missouri Pacific decision. Again the Commission may conclude that in the case of small issues of a local character, as in the Plaza-Olive decision, underwriters are the most likely persons to come forward and that this should not be discouraged. In the Chicago, Milwaukee, St. Paul \& Pacific Railroad Company Reorganization, authority was denied an applicant seeking to be a member of the preferred stockholders' committee because the member owned a one-fourth interest in a firm which in turn owned a large amount of the debtor's bonds. ${ }^{45}$ This was held to indicate "a predominant pecuniary interest likely to be in conflict with his interest as a stockholder." ${ }^{\prime 6}$ On the other hand, ownership of the securities which the committee has sought to represent has been held not to be a disqualification. ${ }^{47}$

The Commission has insisted also that it retain control over the personnel of committees by requiring appropriate provisions in deposit agreements and authorizations to the effect that additional members or members elected to fill vacancies must be approved by the Commission. ${ }^{45}$ This is a condition which appears in all orders of the Commission granting authority.

\section{Interstate Commerce Commission requirements as to deposit agreements and authorizations}

In its attempt to determine whether a proposed solicitation will be "reasonable, fair, and in the public interest," the Interstate Commerce Commission is obliged to scrutinize carefully the deposit agreement or authorization under which the applicant proposes to act. The Commission is particularly concerned that the deposit agreement be fair to depositors, not "one-sided," and that it be so drafted that members cannot elude their responsibilities. ${ }^{49}$ Any lawyer can now, by a study of the cases heretofore decided by the Commission, determine in advance of drafting a deposit agreement upon what the Commission is likely to insist. It is proposed to discuss here certain of the more important of these provisions.

44. 224 I. C. C. 405 (1938); cf. Missouri Pacific R. R. Reorg., 230 I. C. C. 5 (1933).

45. 224 I. C. C. 219 (1937).

46. Id., at 223. Accord Chicago \& N. Ry. Reorg., 221 I. C. C. 475 (1937).

47. Id., at 478 .

48. Chicago, M., St. P. \& P. R. R. Reorg., 228 I. C. C. 180 (1938); Chicago \& N. Ry. Reorg., 224 I. C. C. 611 (1938) ; New York, N. H. \& H. R. R. Reorg., 217 I. C. C. 191 (1936) and 221 I. C. C. 37 (1937).

49. Chicago, R. I. \& P. Ry. Reorg., 221 I. C. C. 435 (1937). 
1. Representation of different securities. A committee may occasionally seek authority to represent several types of securities of the same issuer: for example, a junior lien and preferred stock, or preferred and common stock. In two cases which have come before the Commission this practice has not been allowed. In the Missouri Pacific Railroad Company Reorganization, the "Protective Committee for Junior Sectrities" proposed to solicit the convertible and serial bonds, and the preferred and common stock..$^{50}$ During the proceeding, the committee indicated a desire to withdraw its application to solicit bonds. Authority was granted, however, on condition that either common or preferred stock only be solicited. Again in the Chicago \& Northwestern Railzay Company Reorganization, authority to act was granted to the "Committee for Preferred and Common Shareholders" on condition that it consent to act for one or the other. ${ }^{51}$ The Commission made its position clear as follows:

"In our opinion, representation by the committee of the holders of both preferred and common stocks as required in the application would involve a conflict of interest." ${ }^{2}$

2. Adherence to deposit agreement without physical deposit of securities. It was formerly a common practice of committees to permit depositors, frequently institutional holders, to become parties to a deposit agreement without actually depositing bonds. These so-called "agreements to deposit," special arrangements or settlements with non-clepositing bondholders, have not been approved by the Commission. ${ }^{63}$ Where, however, a committee which has commenced to solicit prior to August 1935 , has made such arrangements, these will not be interfered with, but the Commission may require its consent to any such arrangements which may be made after the date of its order granting authority. ${ }^{54}$

3. General pozvers. The Commission has taken the view that the deposit agreement or authorization should be limited to specific proceedings and should not be in general terms. ${ }^{\text {b5 }}$ Such phrases as "irrevocably" and "in the committee's uncontrolled discretion," or "in the sole and unrestricted discretion of the committee," have been frowned upon by the Commission. ${ }^{56}$ Referring to "irrevocably," the Commission has said, "The word as used implies the grant of absolute power and is not in consonance with the express provision permitting the depositor to revoke all powers granted by exercising his right of withdrawal at any time." ${ }^{57}$

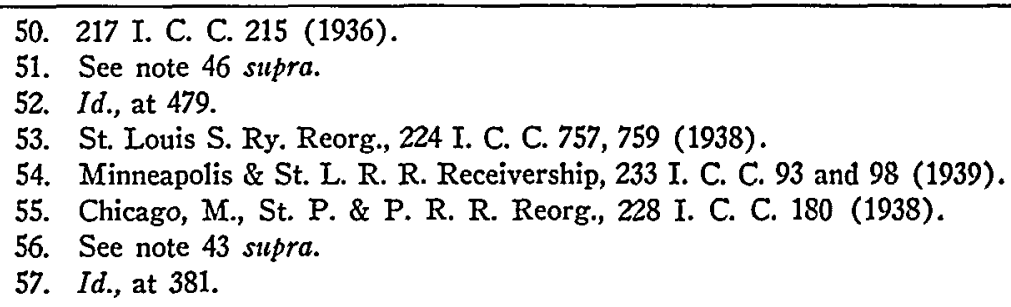


Similarly, exculpatory provisions of agreements have been modified to limit them to preclude the waiver, or attempted waiver, by depositors of negligent acts or acts of wilful misconduct by the committee. In the Behrens Conmmittee case, the application had been denied without prejudice to a renewal of the application on the filing of a revised and amended deposit agreement. 58 In this same case the Commission objected to the provision, common in deposit agreements, that the committee was authorized to construe the agreement and its construction made in good faith should be conclusive and binding. ${ }^{59}$ This, coupled with the broad and vague powers given the committee, was sufficient to warrant a denial of the application.

4. Members dealing in securitics represented by the committee, or underwriting securities of the reorganized company. Provisions permitting members to deal in securities of a company whose securities were deposited with the committee have been condemned in several cases. ${ }^{\text {c3 }}$ In one case the Commission expressed its riew as follows:

"This provision appears to be inimical to the best interest of the depositors. A Committee's action should be independent and not susceptible to the influence of its members by reason of their personal interests in the profits of any undertaking." 01

However, the Commission approves an exception to the prohibition against trading which permits "any member of the committee or any organization with which any member is in any way affiliated or associated" to sell the securities held by him, individually or as a fiduciary, or acquire securities "by gift, inheritance, in payment of, or as security for any debt or obligation, in trust, or as agent." 02

5. Power of committee to vote securitics with respect to a plan. The Commission insists that any plan be submitted to depositors in advance of acceptance by the committee in their behalf. Furthermore, an opportunity must be afforded depositors to withdraw from the agreement. ${ }^{23}$ Notice, of course, must be given to depositors, and this notice should summarize the plan. ${ }^{64}$ This has been required not only where a deposit

58. Missouri Pacific R. R. Reorg., 217 I. C. C. 671 (1937) and compare later report at 221 I. C. C. 282,283 (1937) ; New York, N. H. \& H. R. R. Reorg., 233 I. C. C. 312 (1939).

59. Missouri Pacific R. R. Reorg., 217 I. C. C. 671, 674 (1937).

60. Chicago, R. I. \& P. Ry. Reorg., 221 I. C. C. 435 (1937) : Missouri Pacific R. R. Reorg., 230 I. C. C. 377 (1938) and 224 I. C. C. 405,408 (1938).

61. Missouri Pacific R. R. Reorg., 217 I. C. C. 671,675 (1937).

62. Missouri Pacific R. R. Reorg., 230 I. C. C. 5,12 (1938); Minneapolis \& St. L. R. R. Receivership, 233 I. C. C. 605, 609 (1939).

63. New York, N. H. \& H. R. R. Reorg., 217 I. C. C. 203, 206 (1936); Mlissouri Pacific R. R. Reorg., 224 I. C. C. 405,408 (1938); St. Louis S. Ry. Reorg., 224 I. C. C. 757 (1938) and 221 I. C. C. 179 (1937).

64. See note 43 sipra at 382 . 
agreement has been involved, ${ }^{65}$ but also in the case of authorizations. The requirement seems to be reasonable. As the Commission pointed out in one case:

"From the evidence of record there appears to be active trading in the securities involved, which condition, if it continues, will undoubtedly result in the revocation or modification of certain authorizations given to the committee by security holders. In these circumstances, it is reasonable to infer that the committee will not have accurate knowledge as to the extent of revocation or modification of authorizations given to it, and the Commission could not accept as valid its final acceptance of a plan of reorganization upon submission to the creditors for acceptance or rejection after approval by the Commission and the court." 66

6. Amendments to the deposit agreement or plan, the manner of giving notice to depositors, and the depositors' right to withdraze. The Commission has taken the position that a committee must give depositors notice (generally twenty or thirty days) of the adoption of any amendments to the agreement, or to a plan which had been previously adopted. Furthermore, it should also afford to depositors a right to withdraw their bonds before they will become bound by the amendment. ${ }^{67}$ In criticizing a deposit agreement which provided that the committee shotld give notice of an amendment only if it determined that the amendment affected the interests of depositors "adversely and materially," the Commission stated, "As to what affects his interests adversely or materially, ordinarily the depositor would be the better judge." 68 However, the Commission may approve a provision to the effect that a statement of any amendment to a plan may be filed with the depositaries, "and, if the Interstate Commerce Commission shall determine that any such amendment will not materially affect the rights of depositors adversely, it shall upon such filing and without notice become effective as to all Depositors." 60

In giving notice to depositors of the adoption of amendments to the plan or the deposit agreement, or of termination, the Commission has approved a scheme whereby notice will be mailed to depositors summarizing the action taken or contemplated, and a notice published in one or more newspapers, simply specifying where copies of the amendment, or

65. New York, N. H. \& H. R. R. Reorg., 224 I. C. C. 423, 426 (1938) and 719, 721;

St. Louis S. Ry. Reorg., 224 I. C. C. 106, 109 (1937).

66. New York, N. H. \& H. R. R. Reorg., 224 I. C. C. 423, 426 (1938).

67. New York, N. H. \& H. R. R. Reorg., 217 I. C. C. 60 (1936); Missouri Pacific R. R. Reorg., 230 I. C. C. 377 (1938) and 224 I. C. C. 405 (1938) ; Minneapolis \& St. L. R. R. Receivership, 233 I. C. C. 93 and 350 (1939).

68. New York, N. H. \& H. R. R. Reorg., 217 I. C. C. 60, 66 (1936).

69. Missouri Pacific R. R. Reorg., 230 I. C. C. 377,382 (1938). 
other document, may be obtained. ${ }^{71}$ Usually the period, specified in the agreement, in which depositors may withdraw will run from the date of the first publication of the notice. In this respect, the Commission has been vigilant to protect the depositor's withdrawal rights under an agreement. In granting authority, on the basis of a revised deposit agreement, to the committee of first mortgage bondholders of the Little Rocls and Hot Springs Western Railroad in the Missouri Pacific Reorganization, ${ }^{71}$ the Commission pointed out that the revised agreement provided that "the powers granted to the committee shall not be exercised in any way which will limit, restrict, modify, or deny the right of depositors to dissent or withdraw under the terms and conditions of the agreement which provide for notice to depositors of action proposed by the committee and secure to them the right to dissent from such action and withdraw from the agreement." 72

It seems to be general practice in the case of authorizations, as contrasted with deposit agreements, to permit their cancellation by the security holder at any time on giving notice in writing. Obviously the committee acting pursuant to an authorization which does not call for the physical deposit of bonds is in a much less certain position, so far as definiteness of representation is concerned, ${ }^{73}$ than the committee acting under a deposit agreement where bonds are actually deposited with it. In the latter case, the committee knows that it can count on representing the deposited bonds, for depositors cannot withdraw except under specified circumstances, the more important of which have been noted ahove.

7. Termination or extension of the deposit agreement. The Commission insists upon a definite termination date for the deposit agreement or authorization, with the provision that it may be extended for a further period on application to and approval by the Commission. ${ }^{32}$ Notice must first be published and filed with the depositary, and depositors given an opportunity to withdraw. The agreement may also provide for termination by the committee on a certain number of days' notice, given in the manner above-described, and may provide for termination if requested in writing by depositors holding certificates representing at least fifty-one percent in principal amount of the bonds deposited under the agreement. ${ }^{75}$

8. The committee's accounting and release from liability. One of the most important changes insisted upon by the Commission in deposit

70. Ibid.

71. Missouri Pacific R. R. Reorg., 221 I. C. C. 282 (1937).

72. Id., at 283.

73. New York, N. H. \& H. R. R. Reorg., 224 I. C. C. 423,426 (1938).

74. Missouri Pacific R. R. Reorg., 224 I. C. C. $405,40 S$ (1938) and 230 I. C. C. 5 (1938) ; see note 54 supra.

75. Chicago, R. I. \& P. Ry. Reorg., 221 I. C. C. 435, 442 (1937); St. Louis S. Ry. Reorg., 224 I. C. C. 757, 759 (1938). 
agreements relates to the final winding up of the committee's affairs, the filing of its accounts and the release of the committee from liability. Before the present Regulations were introduced, the agreement commonly provided that at termination the committee should file its accounts with the depositary, and publish notice of that fact. Thereupon depositors would be allowed a period of usually thirty days within which to file objections to the account. All depositors who did not file such objections were deemed to be irrevocably bound by the accounting and to have approved it. This procedure has been modified by the Commission. ${ }^{70}$ It has also modified the effect of the surrender of a certificate of deposit before the termination of the agreement. ${ }^{77}$

Although retaining the scheme for filing accounts, the Commission requires that the deposit agreement provide the committee be released from liability only in respect to that part of the account not objected to specifically. The depositor's objections must set forth his claims and specify items of the account objected to and the grounds of the objection. ${ }^{78}$ Such objections are deemed to be made for his benefit only and the committee is discharged from liability to all other depositors. ${ }^{70}$ While the surrender of certificates will release the committee and depositaries from liability to the holders, the Commission has insisted that the release shall not take effect unless and until a final accounting has been filed and after the expiration of the period within which objections may be filed, and shall not be effective against depositors that have filed objections. This provision is open to the criticism that a person may surrender his certificate, say, in 1936; the committee may not account until years later when its work is terminated. Yet this old depositor may come in on the final accounting and file an objection to the accounts. This hardly seems fair. If he did not have sufficient interest in continuing with the committee, why should he be able to come in at the "wind-up" and object? But perhaps, the chance of this occurring is more theoretical than real. ${ }^{80}$ The Commission has also indirectly indicated its disapproval of a provision permitting a committee to release a resigning member until the final account has been filed. ${ }^{81}$

9. Miscellaneous provisions. The authority of the Commission has been uniformly granted on three conditions common to all committees:

76. Seo notes 43 and 54 supra; Missouri Pacific R. R. Reorg., 224 I. C. C. 405, 409 (1938) ; Chicago, R. I. \& P. Ry. Reorg., 221 I. C. C. 435 (1937); Minneapolis \& St. L. R. R. Receivership, 233 I. C. C. $93,96-98$ (1939).

77. See note 43 supra; St. L. S. Ry. Reorg., 224 I. C. C. 757, 761 (1938).

78. See note 43 supra at 383 .

79. See note 76 supra; cf. Chicago, R. I. \& P. Ry. Reorg., 221 I. C. C. 435,443 (1937) where the committee was to be discharged when its accounts had been approved by the court.

80. See note 77 supra.

81. Chicago, R. I. \& P. Ry. Reorg., 221 I. C. C. $435,440,442-443$ (1937). 
first, that they will abide by the rules and regulations of the Commission as they may be promulgated; second, that they will keep minutes of meetings and records of actions taken; and third, that they will file monthly reports of receipts and disbursements on the first of each month with the Commission's Bureau of Finance. Moreover, a provision of a deposit agreement denying a depositor the right of independently prosecuting a right of action against the debtor without written permission of the committee has been disapproved. ${ }^{82}$ The Commission has also required deletion of a provision which permitted the depositary to advise with counsel for the committee or counsel of its own selection, where action in accordance with the opinion rendered was to furnish the depositary protection..$^{33}$

\section{Financial arrangements of committes}

The belief that control was needed over the financial arrangements of protective committees was one of the most important factors behind the enactment of subsection ( $p$ ). While Section 77 of the Bankruptcy Act had originally provided that committees might obtain both compensation and reimbursement for expenses from the debtor's estate, ${ }^{81}$ the 1935 Amendments took away the possibility of obtaining compensation from this source and confined the allowance which a committee might obtain from the debtor's estate to reimbursement for actual out-of-pocket expenses (including reasonable attorney's fees). ${ }^{85}$ Despite this change, numerous applications by committees for authority to act have contained provisions for an allowance of compensation from the debtor's estate. ${ }^{80}$ The reason for this is not clear. It may be that the Bar has insufficiently

82. See note 43 supra.

83. Id., at 381-382.

84. Subsection (b) (8) of the original Section 77 provided that the court, within maximum limits set by the Interstate Commerce Commission pursuant to subsection (f) might "allow a reasonable compensation for the services rendered and reimbursement for the actual and necessary expenses incurred in connection with the proceeding and plan ... by committees or other representatives of creditors or stocklholders." Subsection (c) (12) of the present act permits the judge (within maximum limits fixed by the Commission) to make an allowance from the debtor's estate to committees or other representatives of creditors or stockholders "for the actual and reasonable expenses (including reasonable attorney's fees) incurred in connection with the proceedings and plan." Thus by the 1935 amendment committees are no longer entitled to compensulion from the debtor's estate but only actual and reasonable expenses including reasonable attorney's fees. On the other hand, indenture trustees and depositaries are entitled to reasonable compensation from the debtor's estate under present subsection (c) (12).

85. Ibid.

86. Missouri Pacific R. R. Reorg., 230 I. C. C. 5, 10-11 (1938); New York, N. H. \& H. R. R. Reorg., 224 I. C. C. 423,425 (1938); St. Louis S. Ry. Reorg., 224 I. C. C. 105, 109 (1937); Chicago, M., St. P. \& P. R. R. Reorg., 228 I. C. C. 180, 184 (1938); Chicago, I. \& L. Ry. Reorg., 221 I. C. C. 549, 553 (1937) and 224 I. C. C. 495 (1938). 
apprehended the purport of the 1935 Amendments, or that the applications have contained these provisions out of the hope that a change may be made in the Act, as in fact the pending reorganization bill introduced by Senator Wheeler would provide. ${ }^{87}$ Nevertheless the Commission, in the face of these applications, has not insisted that such provisions be stricken. But it has, however, warned that it does not possess the power to fix maximum limits of compensation, since Section 77 (c) 12 does not mention compensation. ${ }^{88}$ Consequently it has stated that authorization to the committee is not to be construed as approval of the right of the committee to compensation, or even as approval of the filing by the committee of an application therefor. ${ }^{80}$ A reasonable charge for compensation may of course be provided in a lien on deposited bonds payable on withdrawal or on the termination of the committee, or out of the proceeds of securities received by depositing bondholders in the reorganization. ${ }^{\text {00 }}$ But where the committee does not waive compensation or expressly provicle that its compensation is to be a lien against depositing bondholders, the Commission has required that all "circulars and advertisements soliciting the deposit of bonds and authority to represent the depositors should apprise bondholders that such compensation may have to be paid out of advances by them or out of the proceeds of the disposition of their bonds." 01 Accordingly, the Commission's authorization to the committee in that case was so conditioned. Even in cases where the committee provides that only expenses be reimbursed from the debtor's estate, the Commission has pointed out that its authorization of such a provision in an agreement is not to be construed as approval of expenditures contemplated or as fixing maximum limits within the meaning of Section 77 (c)12, for which purpose a hearing and inquiry into the reasonableness of such expenses in necessary. ${ }^{92}$

The Commission insists that the provisions of the deposit agreement must be consistent with respect to the maximum amount of bonds which may be charged for expenses and compensation, the maximum lien which the committee has against the bonds, and the maximum limit of the committee's borrowing power and the corresponding right to pledge deposited bonds for this amount. ${ }^{33}$ Any discrimination between bondholders in respect to such charges has been condemned. ${ }^{94}$ Under certain circum-

87. See note 15 supra.

88. Chicago, M., St. P. \& P. R. R. Reorg., 228 I. C. C. 180, 184 (1938).

89. Id., at 185 ; see note 86 supra.

90. Missouri Pacific R. R. Reorg., 230 I. C. C. 5 (1938).

91. Chicago, I. \& L. Ry. Reorg., 221 I. C. C. $549,553-554$ (1937).

92. Chicago, I. \& L. Ry. Reorg., 224 I. C. C. 495,499 (1938).

93. Missouri Pacific R. R. Reorg., 221 I. C. C. 405 (1938) ; Chicago, R. I. \& P. Ry. Reorg., 221 I. C. C. 435 (1937).

94. Chicago, M., St. P. \& P. R. R. Reorg., 228 I. C. C. 180, 184 (1938). 
stances, committees have been permitted to borrow money in advance of the deposit of any bonds for the purpose of commencing solicitation. ${ }^{95}$ The Commission, moreover, in the case of committees seeling authority to solicit powers of attorney rather than the physical deposit of bonds under an agreement, has approved an agreement to contribute a maximum of $\$ .20$ a share, $\$ .10$ payable at once and $\$ .10$ on call within six months. ${ }^{96}$ In the case of certain committees for junior liens and equities, the committees have stated that they expect to save expense by having secretarial work done by a central organization attached to the National Council of Investors. ${ }^{37}$ Thile not disapproving of this arrangement, the Commission has stated that the responsibility for economical administration of the affairs of the committee "rests squarely with the Committee members" and authorization in the cases where this has been proposed was not to be considered as approval of the proposed arrangement, "nor as assurance that the amounts of payment to the central organization will be accepted by the committee as proper items of expense of the committee." 98

From a consideration of numerous factors, such as the amount of bonds which the committee expects to obtain and the character of the reorganization, the Commission will approve a maximum amount, usually a percentage of the face amount of deposited bonds, or a fixed amount per share, which the committee may charge depositors. It is impossible to generalize on the amount which will under the circumstances be approved. Amounts approved in deposit agreements relating to bonds have varied from three tenths of one percent ${ }^{93}$ to three percent. ${ }^{109}$ Of course, another problem arises where the applicant is a committee which has acted prior to the effective date of subsection (p) and seeks authority to continue to act. Since the Commission in such a situation cannot grant authority on terms which will invalidate past acts, ${ }^{101}$ the prior charges for expenses against deposited bonds will not be disturbed, but the Commission will set a limit on future expenses. ${ }^{102}$ In one case, the deposit agreement had originally permitted two percent; at the time of the application expenses amounting to approximately one and one-half percent

95. Chicago, M. \& St. P. R. R. Reorg., 228 I. C. C. 180, 184 (1938); Chicago, I. \& L. Ry. Reorg., 221 I. C. C. 549, 556 (1937) ; New York, N. H. \& H. R. R. Reorg., 217 I. C. C. 191 (1936).

96. New York, N. H. \& H. R. R. Reorg., 224 I. C. C. 307,310 (1937).

97. Ibid; Chicago, M., St. P. \& P. R. R. Reorg., 224 I. C. C. 219 (1937).

98. Id., at 222 .

99. See note 94 supra.

100. Missouri Pacific R. R. Reorg., 217 I. C. C. 671 (1937).

101. See note 2 supra.

102. Minneapolis \& St. L. R. R. Receivership, 233 I. C. C. 93,350 and 608 (1939); cf. note 43 supra. 
had been incurred. The Commission limited future expenses to one-half of one percent. ${ }^{103}$

Establishing a differential between expenses to be charged against bondholders depositing before and those depositing after the Commission's order creates a difficult problem from the "securities angle," especially if the certificates are listed on an exchange. Any new deposits of bonds will require the issuance of new and distinct certificates, because of the fact that holders of "old" certificates may be subject, for example, to a $\$ 20$ charge per $\$ 1,000$ bond, while holders of "new" certificates may be subject to a charge of only $\$ 5$. This situation will result, of necessity, in two quotations on the board. Consequently, a stock exchange would have to require that a new listing be filed; and probably a new registration under the Securities Exchange Act would be necessary. A committee, in this situation, should carefully weigh the possibility of its obtaining substantial new deposits and should determine whether the "listing difficulties" do not make it wiser not to attempt to secure future deposits. In the event that larger holders should desire to deposit with the committee, the Commission's approval of an "agreement to deposit" without the physical deposit of bonds could be applied for, and if the arrangement were advantageous, the application would probably be obtained.

\section{Conclusion}

The discussion above has attempted to outline the scope and detail of the regulation by the Interstate Commerce Commission of protective committees in railroad reorganizations. The drafting of deposit agreements by negotiation between the Commission and the committee (which is the result of the existing Regulations) is of great significance from the contract standpoint. Deposit agreements have traditionally been treated by the courts as contracts between the committee and the depositing security holders with which the reorganization court will not interfere. ${ }^{104}$ What has evolved from Section $77(p)$ is a species of "collective bargaining" for security holders with the Commission in the role of a bargaining agent.

Comment has been made on the failure of the Administration to press for passage of the Lea Bill ${ }^{105}$ at this session of Congress. Perhaps the Securities and Exchange Commission desires to watch further the experiment in regulation of protective committees under Section $77(p)$ of the Bankruptcy Act. At any rate, this regulation will bear considerable watching; it is the first extensive attempt to control protective committees in corporate reorganizations.

103. Ibid; cf. note 54 supra.

104. Habirshaw Electric Cable Co. v. Habirshaw Electric Cable Co., Inc., 296 Fed. 875 (C. C. A. 2d, 1924), cert. denied stb nom., Whitman v. Bondholders Committee, 256 U. S. 587 (1924).

105. See note 32 sipra. 